\title{
Pension fund: a veritable source of financing real estate development in Nigeria
}

\author{
Adjekophori Bernard \\ Estate Management Department, Federal Polytechnic Auchi, Edo State, Nigeria \\ E-mail address: benejis@gmail.com
}

\begin{abstract}
Pension funds control relatively large amounts of capital and represent the largest institutional investors in many nations. Financing real estate on the other hand required a huge capital outlay. This study examined the viability of pension funds as an investment option in real estate development. It is empirical in approach and it adopted a survey research design. A convenient random sampling technique was used to gather data from a sample of 42 respondents comprising of 18 pension administrators and 24 Real Estate Developers and Investors. A structured questionnaire was used as the instrument for data collection and a simple descriptive statistical method was use for presentation and analysis of the data. The results however reveal that both the pension administrators and the real estate developers agreed that the pension funds if well channel is a veritable means for financing real estate project. We therefore recommends amongst others that the government as a matter of urgency should slack their policy to increase the percentage of the funds for real estate development and to also advance a policy with strict guideline empowering the pension fund managers to directly grant credit to developers and real estate investors who is able to meet and comply with the conditions provided in such policy. Real estate brokers and experts should also be drafted into the pension scheme to give professional advice on the viability and feasibility of any proposed real estate development.
\end{abstract}

Keywords: Pension Fund; Pension Manager; Real Estate Finance; Development; Investment; Viable Means

\section{INTRODUCTION}

The provision of affordable housing at scale remains a challenge to most countries particularly those in developing and transition. It has become increasingly glaring that most urban population according to Nubi (2000), live in dehumanizing housing environment, while those that have access to average housing do so at abnormal cost. Housing has remained independent phenomenon that affects every facets of mankind. It constitute a significance index for man`s wealth (Lea, 2000; Renaud 2004; Babalakin 2004).

Boykin (1979) explained that the real estate touches the economics lives of all individuals and families. It is the cornerstone of community life, the center of family activities and reference point for societal esteem, as well as the most important financial asset most household will ever acquire (Nevota, 2010). 
Despite the prominent role of this basic need, finance has remained a bane to its provision and development. Finance constitutes a fundamental centerpiece in any real estate development as proper funding is all-important to successful property investment and development. Ogedengbe and Adesopo (2003) assert that the performance of any housing finance system will, depend primarily on the volume of fund with in the economy and the proportion of it that can be spread, mobilized and dedicated to housing. Where there is a well structured finance system according to Renaud (2004), the city appears to be well organized with built houses.

In many part of the world, most especially the developed countries, the sources of real estate finance is from government, individual savings, life insurance pension fund and loan institutions( mortgage institution or building societies (Ayedun and Oluwatobi, 2011). But in Nigeria, the bulk of housing stock are financed and constructed through individual efforts.

The pension funds, like the National Providence fund collected from employers and employees towards their retirement, gives access to long term fund and in a good position to finance housing development (Nubi, 2000). In agreement with the above position, Emoh and Nwachukwu (2011) posit that the pension funds are significant provider of long term finance for capital investment in developed societies. They further said that the income derived from such investment in accordance with the policy of the pension fund would be used to cover the cost of servicing the funds and to meet the demand of contributors at retirement.

There is no doubt that finance is an important factor in real estate development. Lack of long-term finance to develop mass housing is a major hindrance. After 50 years of Nigeria independence, a vibrant mortgage market is yet to be developed (Ojo, 2009; Yinka, 2011; Nubi 2002). The existing mortgage scheme that should provide cheaper housing development loan is grossly incapable of satisfying the needs of the populace.

Giving the funding challenge, it becomes clear that the dearth of long-term deposit, couple with low level of capitalization of PMIs in Nigeria and failure to develop a virile mortgage market, financing real estate development will continue to suffer. Pension fund collected from employers especially government organizations and large business concerns and other employees can offer a long-term prospect for funding real estate development since contributors can only receive their benefits at retirement.

This paper therefore, represents an attempt to ascertain the viability of pension funds as a veritable source and an investment option for of real estate development finance in Nigeria.

\section{Objectives}

To examine the existing finance option has affected housing delivery in Nigeria.

To examine the extent to which pension funds will serve as a viable and alternative means for real estate financing.

To identify the militating factors hindering pension funds as an investment in real estate development?

To propose a possible means by which pension funds can properly channel towards real estate development and investment option for pension managers. 


\section{Research Questions}

In light of the above aim, the study will provide answer to the following research questions

- What is the existing funding option for real estate development and how has these affect housing delivery in Nigeria?

- To what extent will pension funds serve as a viable and alternative means for real estate financing?

- What are the militating factors hindering pension funds investment in real estate development?

- How can the pension fund be properly channel towards real estate development to become a viable investment option for pension funds managers?

\section{Research Hypothesis}

H1 Pension fund is not a veritable means for financing real estate development.

H2: Pension managers does not understand the workings of real estate investment

H3: $\quad$ Finance is not a hindrance to effective housing delivery

\section{LITERATURE REVIEW}

Volume has been written in the literature of real estate finance and housing in general, and the concepts have been variously described. Real estate finance can view as the fund needed to carry out real estate development and other related operations. Finance is an essential ingredient of modern day real estate development and most large scale development would not take their present scale without substantial credit (Ogedengbe and Adesopo, 2003).

Many studies has been carried out in respect to pension funds and real estate, some of this study are theoretical and others empirical. For instance, pension funds is Ghana according to Dei (2001) is handle by Social Security and Insurance Trust and they invest in residential housing through organized primary and secondary mortgage institutions. In Zambia, pension funds are potential sources of capital fund. Only public sector pension is legally invested in mortgage finance according to Gardner (2007). In Botswana, Rudloff (2007) adopted focus group discussion in his study and discovered that investment of pension funds in real estate is done exclusively in commercial properties. In the study of Adewumi and Nubi (2011), Walmsley (2007), it was posited that pension funds in Nigeria can be invested in real estate through REITs and MBS. The current paper learn credence from these other studies but also examine the extent to which pension funds can serve as alternative viable source for real estate development and suggest a possible ways of improving the prevailing situation.

One of the most important developments in the flow of funds into real estate has been the entry of pension funds as lenders investors. (Brueggeman, et. al. 1997) These authors further observed that, Insurance companies trust department of commercial banks and investment companies are becoming increasingly cognizant of the magnitude of pension funds market. In essence, pension funds are simply funds accumulated from the contributions made during the working life of individuals that provides them with income during retirement. (Brueggeman, et. al.1997).

According to Imam (2011), pension fund are funds established by an employer to facilitate and organize the investment of employees' retirement funds contributed by the employer and employees. The pension fund is a common asset pool meant to generate stable 
growth over the long term, and provide pensions for employees when they reach the end of their working years and commence retirement. Pension funds are commonly run by some sort of financial intermediary for the company and its employees, although some larger corporations operate their pension funds in-house. Pension funds control relatively large amounts of capital and represent the largest institutional investors in many nations. Nubi, (2002) observed that the pension, usually look for investment that offer long term prospects and are inflation proof like real property development or acquisition. They also offer loans on long-term basis to building societies and mortgage institutions. This further underscores the viability of pension fund for real estate development.

\section{1. Historical Development of Pension in Nigeria}

The history of pension world-wide can be traced to Germany (Njuguna, 2010). The Former German Chancellor Otto Von Bismarck was credited for enacting a compulsory savings programme for workers in large firms who were exposed to the socialism ideologies in 1889 (Guinan 2003, Curtler and Johnson 2004, Newmann 2005 and Langley, 2006). In Nigeria, the development of pension schemes can be traced to the beginning of organized workforces in the private and public sectors in the colonial era of the 20th century (Barrow, 2008). The first pension law in Nigeria was known as the Pension Ordinance of 1951, and provided for the full pension rights of the colonial administrators and partial right granted at the discretion of the colonial Governor General for Nigerian workers in the civil service at that time. This ordinance transformed into the Pension Act of 1958 (Barrow, 2008). The National Provident Fund (NPF) scheme established in 1961 was the first legislation enacted to address pension matters of private organizations (Sule, et.al 2011). It was followed 18 years later by the Pension Act No. 102 of 1979 (Udoji Commission) as well as the Armed Forces Pension Act No. 103 of the same year (Barrow, 2008). The police and other Government Agencies' Pension Scheme were enacted under Pension Act No. 75 of 1987, followed by the Local Government Pension Edict which culminated into the establishment of the Local Government Staff Pension Board of 1987. While in 1993, the National Social Insurance Trust Fund (NSITF) scheme was established to replace the defunct NPF scheme with effect from $1^{\text {st }}$ July, 1994 to cater for employees in the private sector of the economy against loss of employment income in old age invalidity or death (Sule et. al, 2011).

These Decrees remained the operative laws on public service and military pension in Nigeria until July, 2004. However, there were several government circulars and regulations issued to alter their provisions and implementations. For example, mandatory retirement at the age of 60 years or 35 years of service, whichever comes earlier in 1988, and in 1992, the qualifying period for gratuity and pensions were reduced from 10 years to 5 years and from 15 years to 10 years respectively (Barrow, 2008) In 1997, parastatals were allowed to have individual pension arrangements for their staff and appoint Boards of Trustees (BOT) to administer their pension plans as specified in a Standard Trust Deed and Rules prepared by the Office of the Head of Service of the Federation. Each BOT was free to decide on whether to maintain an insured scheme or self-administered arrangement.

There were three regulators in the pension industry prior to the enactment of the Pension Reform Act 2004, namely Securities and Exchange Commission (SEC), National Insurance Commission (NAICOM) and the Joint Tax Board (JTB). SEC licensed pension fund managers while NAICOM is still the agency responsible for licensing and regulating insurance companies in the country. The JTB approved and monitored all private pension schemes with enabling powers from Schedule 3 of the Personal Income Tax Decree 104 of 1993 (Bassey et al, 2010). According to Balogun (2006), most public organizations operated 
a Defined Benefit (pay-as-you-go) Scheme before the enactment of Pension Reform Act 2004. Final entitlements were based on length of service and terminal emoluments. The Defined Benefit (DB) Scheme was funded by Federal Government through budgetary allocation and administered by Pensions Department of the Office of Head of Service of the Federation.

The Pension Reform Act 2004 is the most recent legislation of the Federal Government aimed at addressing the associated problems of the old Pension System. It established a uniform Pension System for both the public and private sectors respectively. Similarly, for the first time in the history of the country, a single authority has been established (National Pension Commission) to regulate all pension matters in the country (Sogunle, 2011).

\section{2. Pension Fund and Real Estate Investment in Nigeria}

Nigeria pension fund seem to be bias for non- real estate related investment. Pension managers are more interested in the capital and money market securities. This situation can be linked to the pension investment in the UK that has declining trend in real estate investment (Isaac 1998; London 1996). Isaac and London also observed that the pension fund administrators in UK showed a preference for the capital and money market as reported by Udoetuk (2008). The same can be said of Nigeria pension fund situation.

Bruggerman et. al. (1997), Isaac (1998), London (1996), adduced reasons for the preference of UK pension managers against non real estate related investment as follows:

- Real estate is perceived as a high-risk investment area, ill suited to the trustee fiduciary character of pension funds.

- Real estate in labour intensive and expensive to manage; demands involved in managing properties have discouraged pension funds managers, as they tend to be passive investors

- Most managers and advisers of pension funds are trained in security (equity and fixed income) analysis, thus they have little or no expertise in the intricacies of real estate investment. To such manager, real estate is riskier, illiquid, difficult to value and is considered long term investment in comparison with equities/ securities

- The real estate market is characterized with lack of adequate information of the type needed to perform comprehensive investment analysis.

As said earlier in this paper, the pension fund in Nigeria can be linked to the one operating in Britain. The above stated reasons for not investing in real estate in the UK can also be said to apply to the Nigeria pension managers. Pension funds are important to shareholders of listed and private companies.

They are especially important to the stock market where large institutional investors dominate. The largest 300 pension funds collectively hold about $\$ 6$ trillion in assets. In January 2008, The Economist reported that Morgan Stanley estimates that pension funds worldwide hold over US\$20 trillion in assets, the largest for any category of investor ahead of mutual funds, insurance companies, currency reserves, sovereign wealth funds, hedge funds, or private equity

As at today in Nigeria, we have about N3 trillion pension assets that have been contributed. The growth rate per annum is about 25 to 30 percent annual growth of pension asset. Hopefully in the next five years you can estimate what that means. It is a gradual process and it has been consistent so far (Umar \& Emmanuel, 2012) 


\section{3. Investment of Pension Fund}

The main concern of the new pension scheme is safety of the fund and the maintenance of fair returns on the amount invested (Section 72 Pension Act 2004). The need for safety is emphasized in determining the quality of the instrument to invest in and a PFA is expected to adopt risk management profile in making investment decisions with due regard to the credit rating of companies registered under the investment and Securities Acts of 1999. PFA was expected to appoint risk management and investment strategy committees. The risk management committee determines the risk profile of investment portfolio and ensures adequate internal control measures and procedures. The investment strategy committee determines the portfolio mix consistent with the risk profile, evaluate and review the performance of investment on periodic basis (Table A).

Table A. Portfolio of Pension Funds as at December 2010.

\begin{tabular}{|c|c|c|c|c|c|}
\hline \multirow{2}{*}{$\mathrm{S} / \mathrm{N}$} & Asset Classes & $\mathbf{2 0 1 0}$ & $\mathbf{2 0 0 9}$ & $\mathbf{2 0 0 8}$ & $\mathbf{2 0 0 7}$ \\
\cline { 3 - 6 } & Local Ordinary Share & $\begin{array}{c}\text { Amount } \\
\text { (N Billion) }\end{array}$ & $\begin{array}{c}\text { Amount } \\
\text { (N Billion) }\end{array}$ & $\begin{array}{c}\text { Amount } \\
\text { (N Billion) }\end{array}$ & $\begin{array}{c}\text { Amount } \\
\text { (N Billion) }\end{array}$ \\
\hline 1. & Foreign Ordinary Share & 24.10 & 2.80 & 2.23 & 3.06 \\
\hline 2. & FGN Security & 829.90 & 498.88 & 350.67 & 279.69 \\
\hline 3 & State Government Security & 69.20 & 33.71 & 0.16 & 0.05 \\
\hline 4 & Corporate Debt Security & 50.73 & 31.18 & 15.13 & 0.24 \\
\hline 5 & Local Money Market Security & 489.23 & 542.22 & 332.44 & 159.92 \\
\hline 6 & Foreign money market security & 7.36 & 17.72 & 17.25 & 26.09 \\
\hline 7 & Open/Closed Ended Funds & 8.61 & 5.74 & 9.03 & 4.46 \\
\hline 8 & REAL ESTATE PROPERTIES & $\mathbf{1 7 0 . 5 2}$ & $\mathbf{1 4 2 . 9 6}$ & $\mathbf{1 2 5 . 5 0}$ & $\mathbf{7 9 . 0 8}$ \\
\hline 9 & Unquoted Securities & 8.61 & 6.18 & 6.86 & 4.43 \\
\hline 10 & Cash And others Assets & 14.19 & 27.53 & 19.20 & 17.79 \\
\hline 11 & & & & & 240.38 \\
\hline
\end{tabular}

Source: Pencom Annual report 2007-2010.

\section{4. Demand for housing finance}

The Nigerian housing finance market is structured along informal and formal sectors. The formal sector has two components: the upper-income groups, whose activities are located in the urban areas, and the lower income groups which rely on the subsidized NHTF for access to housing. The informal sector includes the esusu (rotating savings and loan associations), the traditional co-operative system, credit co-operatives, and individual and family savings. 
Several factors make the environment for mortgage lending difficult, including the absence of clear property and security rights; mandatory governor's consent; high interest rates; and inadequate sources of long-term funding

Nigeria's housing deficit presents an enormous potential for housing and housing finance investors. The country requires N49 trillion (US\$326 billion) to meet its housing demand (EFInA, 2010). However, the outstanding credit to the economy as at December 2008 by financial institutions was put at $\$ 20$ billion. Outstanding mortgage loans are $0.5 \%$ of GDP (2005), compared to $77 \%$ in US, $80 \%$ in UK, $50 \%$ in Hong Kong, and $33 \%$ in Malaysia. 49 Housing finance needs derive mostly from population growth in the urban areas of the country. With a rural urban migration rate of about $5.5 \%$, it is expected that Lagos, for instance, will reach 23.5 million by 2015 . Generally, an increase in population translates into an increase in the demand for housing finance. Effective demand and home ownership relates to affordability, and this is based on household incomes. A review of EFInA's Access to financial services in Nigeria, 2008 survey showed several key findings relating to home ownership.

\section{METHODOLOGY}

The underpinning methodology adopted in this study is a combination of recent literatures and survey results with emphasis on the viability of pension funds as a source of real estate development. Self administered questionnaires with close ended questions suitable for quantitative analysis with few open ended qualitative questions were used to elicit information from real estate developers and pension funds managers in Lagos state being the study area. According to Glenn (2009), there are several approaches to determining a sample size. These include using a census for small populations, imitating a sample size of similar studies, using published tables, and applying formulas to calculate a sample size. Because of the available time in completing this study, a small population in line with similar studies was adopted is this paper, therefore, a total number of 24 developers and 18 pension managers all together 42 respondents were used as the study sample frame. A convenient random sampling technique was adopted for the exercise due to the way and manner the respondents are located within the metropolis. For a more elaborate and deeper insight to the issue under focus, personal interview was also used to gather primary information to compliment the questionnaire. Data collected were grouped together and analyzed using simple descriptive statistical methods.

\section{RESULT AND DISCUSSION}

Table 1, represents the respondents' sex distribution. $80.9 \%$ of the are male while about $19.1 \%$ which represent 8 of the 42 respondents used for the study were female, this implies that there are more men respondents that the female in the study

In an attempt to validate some of the opinion of respondents in the study, we probe into the number of years they have been operating as a real estate developer. Our findings however shows that 10 of the 24 developers sampled which represent about $41.7 \%$ of the total respondents have been operating between 1-5 years and 37.5\% between 6-10 years while $20.8 \%$ the total respondent have been in the business for over ten years. It therefore means that a good percentage of $(58.3 \%)$ the respondents have been operating with 6 years 
and above and will be in good position to give a fair response and opinion to the property finance in the study environment this is shown in Table 2 in the appendix.

Table 1. Respondents Sex Distributions.

\begin{tabular}{|c|c|c|}
\hline SEX & FREQUENCY & PERCENTAGE \\
\hline MALE & 8 & 19.1 \\
\hline FEMALE & 34 & 80.9 \\
\hline TOTAL & 42 & 100 \\
\hline
\end{tabular}

Source: Survey Feb, 2013.

Table 2. Respondent Distribution Year of Operations as a Developer.

\begin{tabular}{|c|c|c|}
\hline $\begin{array}{c}\text { LENGTH OF } \\
\text { OPERATION }\end{array}$ & FREQUENCY & PERCENTAGE \\
\hline $0-5$ YRS & 10 & 41.7 \\
\hline $6-10$ YRS & 9 & 37.5 \\
\hline ABOVE 10YRS & 5 & 20.8 \\
\hline TOTAL & 24 & 100 \\
\hline
\end{tabular}

Source: Survey Feb, 2013.

From the pension managers' perspective, we also sought to know how long they have been in pension fund managers and investment. Table 3 presents their response and it shows that most of them have been in the scheme with $1-10$ years. $50 \%$ fall with those between $0-5$ years while 7 respondents $(38.9 \%)$ were those that have been in the scheme for between $6-10$ years and only $2(11.1 \%)$ have spent over ten years in the scheme of managing pension funds. We can also conclude that averagely the respondents are qualified to give a fair representation of the pension

fund investment option.

Table 4 considered the awareness level of respondent to the availability and existence of government pension scheme. The analysis reveals that a good percentage of them are aware of the scheme. $83.3 \%$ (20) attested to this by agreeing that they are very much aware of it and $16.6 \%$ also concur to the awareness of the pension fund. That is to mean that all the respondents have good information about the existence of government pension scheme in Nigeria.

Our intention is to find out if pension funds can provide a viable option to financing real estate development in Nigeria. We deliberately put forward this question to know how many real estate project the pension scheme have directly finance. The analysis reveals that from all the respondents, only 2. (11.1\%) has ever invested in real estate directly. While 88.9 $\%$ said that they never delve into real estate development since they been managing pension fund. This can have a very great impact on housing delivery since real estate development requires huge capital and long term investment which can be easily provided by the pension scheme based on their nature. (See Table 5) 
Table 3. Respondent Distribution of Year of Operations as a Pension Administrator.

\begin{tabular}{|c|c|c|}
\hline $\begin{array}{c}\text { LENGTH OF } \\
\text { OPERATION }\end{array}$ & FREQUENCY & PERCENTAGE \\
\hline $0-5$ YRS & 9 & 50 \\
\hline 6-10YRS & 7 & 38.9 \\
\hline ABOVE 10YRS & 2 & 11.1 \\
\hline TOTAL & 18 & 100 \\
\hline
\end{tabular}

Source: Survey Feb, 2013.

Table 4. Awareness of Government Pension Scheme.

\begin{tabular}{|c|c|c|}
\hline OPINION & FREQUENCY & PERCENTAGE \\
\hline $\begin{array}{c}\text { VERY MUCH } \\
\text { AWARE }\end{array}$ & 20 & 83.3 \\
\hline AWARE & 4 & 16.6 \\
\hline NOT AWARE & - & 100 \\
\hline TOTAL & 24 & \\
\hline
\end{tabular}

Source: Survey Feb, 2013.

Table 5. Opinion to Having ever Finance Real Estate Development.

\begin{tabular}{|c|c|c|}
\hline & FREQUENCY & PERCENTAGE \\
\hline YES & 2 & 11.1 \\
\hline HAVE NOT & 16 & 88.9 \\
\hline INDIFFERENT & - & - \\
\hline TOTAL & 18 & 100 \\
\hline
\end{tabular}

Source: Survey Feb, 2013.

In a bid to further re affirm the pension managers position of having ever financed real estate development, we also try to find out from the developers how many time they ever finance housing using pension fund. Their opinion is not different either as all the respondents unanimously $(100 \%)$ said they never fund any project using the pension fund (see Table 6). 
Table 6. Opinion to having ever Finance Real estate with Pension fund.

\begin{tabular}{|l|c|c|}
\hline & FREQUENCY & PERCENTAGE \\
\hline YES & & \\
\hline HAVE NOT & 24 & 100 \\
\hline INDIFFERENT & - & - \\
\hline TOTAL & 24 & 100 \\
\hline
\end{tabular}

Source: Survey Feb, 2013.s

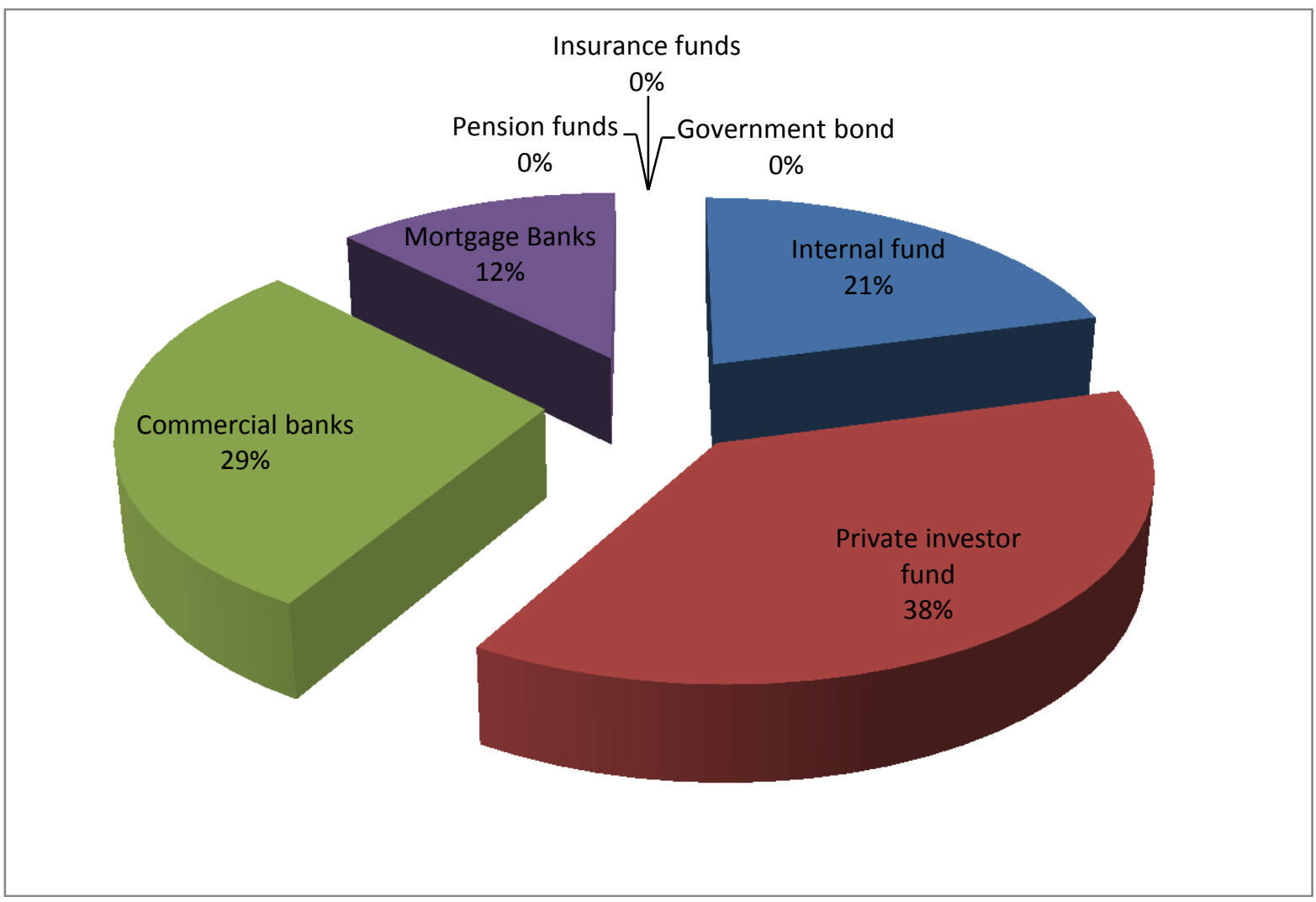

There are various sources of finance option open to investors and real estate developer. Our study reveal that out of these options, $37.5 \%$ of our respondents as shown in the table above normally get their fund from private investors, $20.8 \%$ from internal generated funds and $29 \%$ always approach commercial banks for their finance option while only $12.5 \%$ consider mortgage banks for financing project.

This also left a lot to determine in housing financing and delivery issue in Nigeria. Considering the mortgage financing option of just $12.5 \%$ of the total respondent. How much can internal and private source of finance generate to deliver adequate and affordable housing for the low-medium class in the face of the economic situation in Nigeria today? ( see Table 7). 
Table 7. Source(s) of Financing Real Estate Development.

\begin{tabular}{|c|c|c|}
\hline & FREQUENCY & PERCENTAGE \\
\hline Internal fund & 5 & 20.8 \\
\hline $\begin{array}{c}\text { Private investor } \\
\text { fund }\end{array}$ & 9 & 37.5 \\
\hline $\begin{array}{c}\text { Commercial } \\
\text { banks }\end{array}$ & 7 & 29 \\
\hline $\begin{array}{c}\text { Mortgage Banks } \\
\text { Pension funds }\end{array}$ & 3 & 12.5 \\
\hline Insurance funds & - & - \\
\hline $\begin{array}{c}\text { Government } \\
\text { bond }\end{array}$ & - & - \\
\hline TOTAL & 24 & 100 \\
\hline
\end{tabular}

Source: Survey Feb, 2013.

It a condition to as a form of collateral meet certain requirement before assessing loan from any of the sources listed in the previous table. In an attempt to know what the loan requirements are, our respondents as presented Table 8 , shows that certificate of occupancy is the most preferred by grantors as $37.5 \%$ gave their support to this option that you can only get loan from any of the finance source with a valid "C of O".

Table 8. Conditions and Requirements For Granting Loan.

\begin{tabular}{|c|c|c|}
\hline & FREQUENCY & PERCENTAGE \\
\hline C of O & 9 & 37.5 \\
\hline $\begin{array}{c}\text { Approve } \\
\text { building plan }\end{array}$ & - & - \\
\hline $\begin{array}{c}\text { Survey plan \& F } \\
\text { \&V report }\end{array}$ & 3 & 12.5 \\
\hline F and V report & 4 & 16.7 \\
\hline $1,2,3 \& 4$ above & 8 & 33.3 \\
\hline TOTAL & 24 & 100 \\
\hline
\end{tabular}

Source: Survey Feb, 2013.

$33.3 \%$ however said the combination of " $\mathrm{C}$ of O", survey plan and feasibility and viability report is required as a condition to granting housing loan. $16.7 \%$ support Feasibility and viability report as a condition and $12.3 \%$ said it's just survey plan and F\&V report. This 
condition can also make assess to housing loan very difficult sometimes and this can further affect effective and affordable housing delivery system.

From Table 9, we realized that interest rate in the most inhibiting factor to getting loan for real estate finance in Nigeria. $83.8 \%$ of our study respondents from the developers' angle registered their opining to this. $8.3 \%$ however presented loan ceiling by government and excessive protocol and bureaucracy as a major problem in securing loan for housing development.

It could therefore be said that the rate of interest is very high or becoming too high for investors and the protocol and bureaucracy from the institutions/ sources of loan is pose a cogwheel to investors wishing to get loan for housing development.

Table 9. Problems Encounter in Securing Housing Loan.

\begin{tabular}{|c|c|c|}
\hline Problems & FREQUENCY & PERCENTAGE \\
\hline $\begin{array}{l}\text { Collateral } \\
\text { Adequacy }\end{array}$ & - & - \\
\hline $\begin{array}{l}\text { High Interest } \\
\text { Rate }\end{array}$ & 20 & 83.8 \\
\hline $\begin{array}{l}\text { Loan ceiling } \\
\text { and duration }\end{array}$ & 2 & 8.3 \\
\hline $\begin{array}{c}\text { Restriction of } \\
\text { government } \\
\text { policy }\end{array}$ & - & - \\
\hline $\begin{array}{c}\text { Excessive } \\
\text { protocol and } \\
\text { bureaucracy }\end{array}$ & 2 & 8.3 \\
\hline Total & 24 & 100 \\
\hline
\end{tabular}

Source: Survey Feb, 2013.

The main aim of the study is to actually establish the appropriateness of pension funds as a viable and veritable means of financing real estate development. Table 10 presents respondents opinion to the only hypothesis of the study.

This also represents both the pension and real estate investors/developer respondents. From the analysis, it is obvious that most of the respondents are against our hypothesis which was stated in null. $90.5 \%$ of the total respondent are of the opinion that the pension funds can serve a viable and veritable means to financing real estate development, this is represented by $66.7 \%$ strongly agree and $23.8 \%$ agree.

On the contrary, about $9.4 \%$ supported our null hypothesis that state that pension funds can't not be a viable invested means for real estate development. However, this percentage is to minute compare to those that rejected it.

It therefore means that real estate investment and housing delivery can be more effective with the introduction of direct financing option from the pension fund that have adequate capital and long term gestation period. We therefore reject our hypothesis and accept the alternative. 
Table 10. Agreement to the Viability of Pension Funds for Financing Real Estate Development.

\begin{tabular}{|c|c|c|}
\hline Opinion & FREQUENCY & PERCENTAGE \\
\hline $\begin{array}{c}\text { Strongly } \\
\text { Agreement }\end{array}$ & 28 & 66.7 \\
\hline Agree & 10 & 23.8 \\
\hline $\begin{array}{c}\text { Strongly } \\
\text { disagree }\end{array}$ & 1 & 2.4 \\
\hline Disagree & 3 & 7 \\
\hline Total & 42 & 100 \\
\hline
\end{tabular}

Source: Survey Feb, 2013.

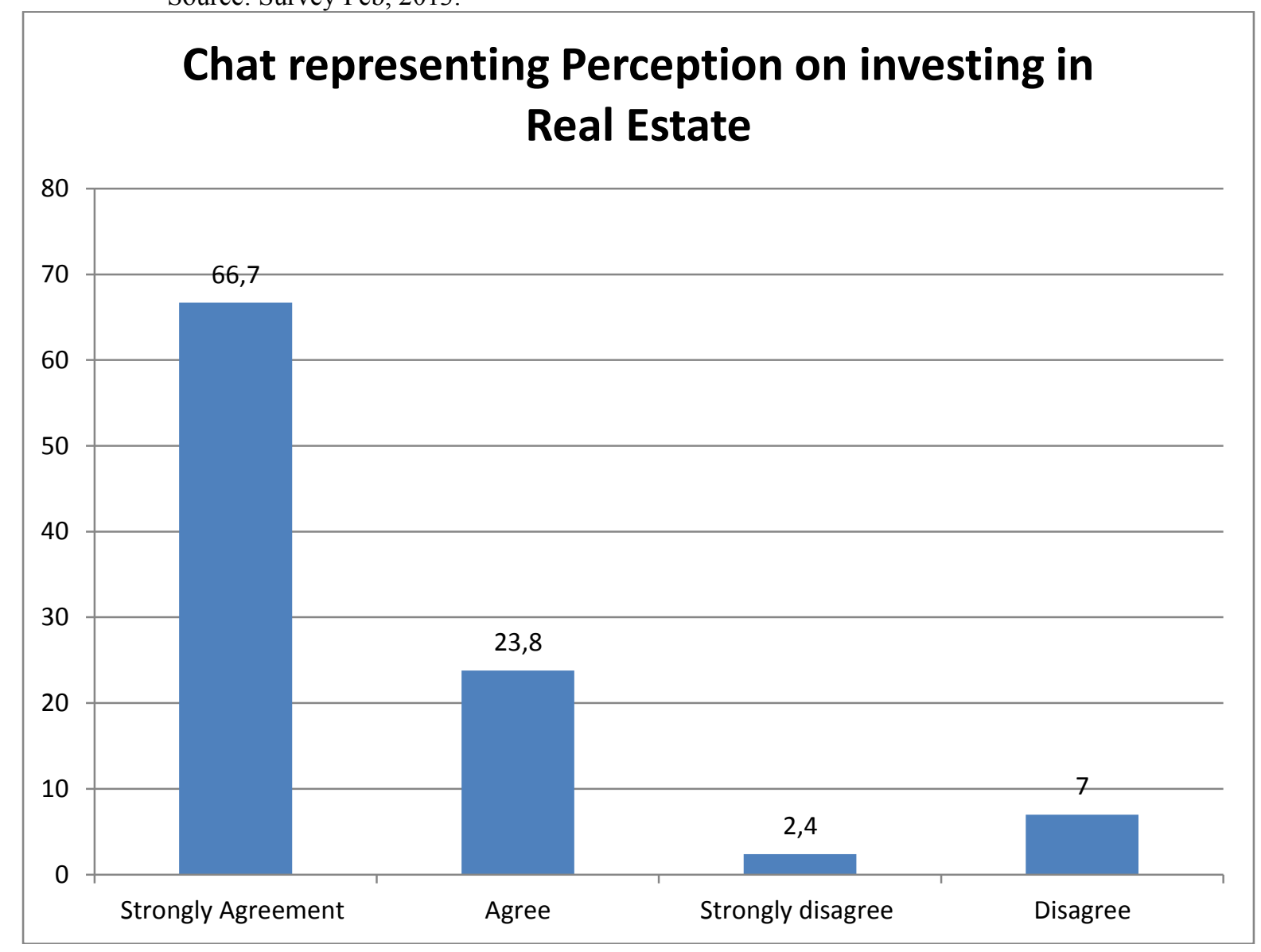

In Table 11, respondent gave a total support to the viability of pension as a source of housing finance, what then could be the reasons or a hindering factor(s) from putting these funds into this investment option as against others? Various opinion was recorded in the course of the study $50 \%$ of the reasons gave was in favour of government policy. 
Table 11. Constraints Against Investing in Real Estate Development.

\begin{tabular}{|c|c|c|}
\hline Reasons & FREQUENCY & PERCENTAGE \\
\hline $\begin{array}{c}\text { Government } \\
\text { policy }\end{array}$ & 9 & 50 \\
\hline Corruption & 4 & 16.7 \\
\hline $\begin{array}{c}\text { Ignorant of } \\
\text { pension } \\
\text { Managers }\end{array}$ & 4 & 22.2 \\
\hline $\begin{array}{c}\text { Insecurity of } \\
\text { investment } \\
\text { option }\end{array}$ & 18 & 22.2 \\
\hline TOTAL & & 100 \\
\hline
\end{tabular}

Source: Survey Feb, 2013.

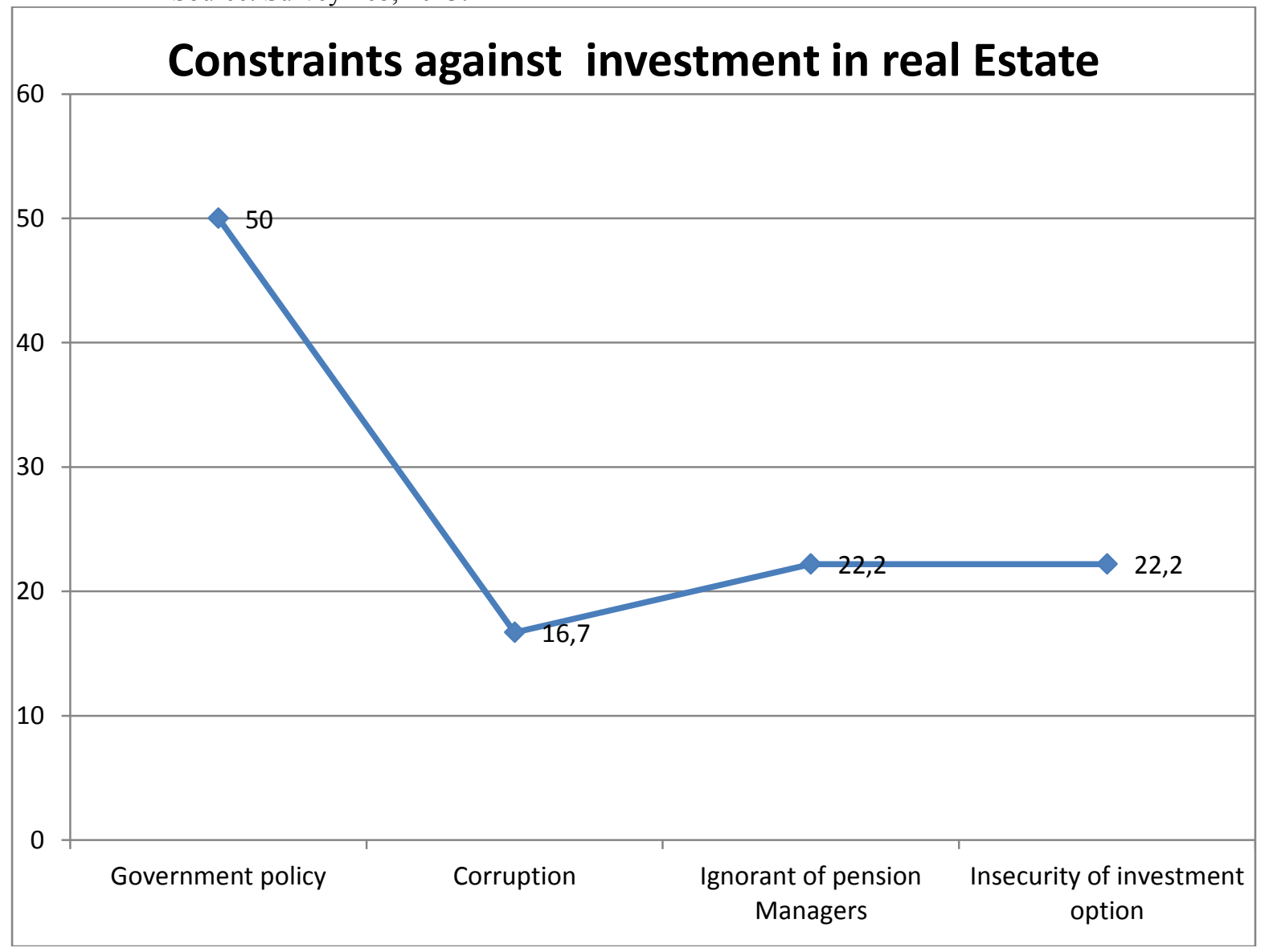

That the policy in place did not favour the investment of pension fund in real estate development. Other reason being that the pension managers are still ignorant of the working of property investment. Therefore they prefer the investment option they understand rather that going into the one they could not really know the working and know how $22.2 \%$ of the respondents gave this reason. The same also percentage goes for the insecurity of the investment option. However, there are some of the respondents that felt that, apart from the 
other reasons, corruption is also an inhibiting factor to putting pension funds on real estate development.

\section{CONCLUSIONS, RECOMMENDATIONS AND POLICY IMPLICATIONS}

The paper has thus far presented an argument in favour of the appropriateness of pension funds as source of real estate development in Nigeria. A lot of facts were reveal from the empirical data as well as the review of similar past researches.

Finance has been said to constitute a fundamental centerpiece in any real estate development and that the ability of a developer to mobilize enough fund for the project determine largely the success of the development. The study has revealed to us that the pension funds have a pull of fund that can be used to finance real estate development. But this obviously with the level of housing provision in Nigeria today apart from other reasons, pension funds impact has not been felt in this sector. If funds are available and not invested or invested in project that may not actually give adequate return, such could be term as capital tied down, that may also give room for other vices, like embezzlement. It is therefore suggested that because of the importance of the real estate sector to all and sundry, pension managers should look into the direction of housing development.

The paper also discover that the major hindrance to investing in real estate development in government policy regarding the investment portfolio of pension funds and managers. According to Odia and Okoye (2012) the government has specify with percentage the nature of investment as well as the medium of going into such investment in the 2004 pension Act. This seems to have handicapped pension manager as to directly investing in real estate project. It therefore mean that a policy should be advance by government with strict guideline empowering the pension fund managers to directly grant credit to developers and real estate investors who is able to meet and comply with the conditions provided such conditions are not again serve as barrier.

It was also discovered that the pension fund favoured the capital market where government bond are securities are traded according to Bruggerman et. al. (1996). This policy somehow can be described as devils gift that is giving with one hand and taking with the other. It is a way of financing their activities at the expense of the citizen that are supposed to be the direct beneficiaries. The government should therefore see it as a matter of urgency to slack their policy put up a review clause and see a reason why a larger percentage should not be given to funding government selfish project.

The capital and money market securities have been lately not too favourable as seen in the negative trends of investment returns in that market. It is a wise decision to constantly balance investment option and diversify into a viable, secure and inflation proof investment, the real estate is a good option that have all these qualities. The pension managers lack the technical knowhow to understand the working of real estate investment (Bruggerman et. al. (1996). They were not train in the analysis of such investment option, the estate surveyors and property market expert should be drafted into the board of pension manager to beef up the expertise and help train other on the need to diversify and invest directly in real estate.

Other sources of financing real estate are available as seen in the paper, but a complimentary effort is required from the pension that have a large pool of fund which are not also needed for immediate use. Because of the capital intensive nature of real estate development, and as seen from the result pension funds will serve a veritable and viable means toward effective housing delivery in Nigeria. 
Real estate finance plays a critical role in the development process by supporting strong market while strengthening the financial sector and strong housing market (Nevota, 2010). The Nigeria Institutions of Estate Surveyors and Valuers should rise up with their various programmes and expertise to educate the governments and financial institutions especially pension managers on the safety of investment in real estate and other attendant's benefits and the need to reconsider funding real estate.

Academics and researchers in real estate and housing finance in general should also advance regular training and enlightenment programmes in forms of seminars and workshops for government officials, pension managers and other stakeholders on the need to diversify investment to real estate development this will further boost investors confident

Regular researches should also be embarked on to help policy makers and also to improve the prevailing situation since change is said to the only thing that is constant.

\section{References}

[1] Ayeduni, C.A. and Oluwatobi, A.O. (2011). Issues and Challenges Militating against the Sustainability of Affordable Housing Provision in Nigeria, Business Management Dynamics, 1(4); 01-08.

[2] Bassey, N. E., Etim, O. U., Asinya, F. A. (2010). "An Overview of the Nigerian Pension Scheme from 1951- 2004”. Global Journal of Humanities. 7 (1 and 2); 61-70.

[3] Barrow, G. (2008). Pension Fund Administration in Nigeria. Abuja, Nigeria: Pen and Pages Ltd.

[4] Emoh, F.I., Nwachukwu, C.C. (2011). Critical Issues in Real Estate Finance as an Index in Building Construction project management Success in Nigeria. American Journal of Social and management science, Vol. 2, No.1 pp. 76-90.

[5] Nevova, T. (2010). Expanding Housing finance to the Underserved in South AsiaMarket review and forward agenda. International Bank for reconstruction/World Bank

[6] Njuguna, A.G. (2010). Strategies to Improve Pension Fund Efficiency in Kenya. An Unpublished Ph.D Thesis of Nelson Mandela Metropolitan University, Port Elizabeth.

[7] Nubi, T.O (2000). "Financing urban Housing": A paper delivered in a workshop organized By Nigeria Institute of Building and Road research.

[8] Nubi, T.O (2002). Flying with one wing: Dilemma of mortgage banking in Nigeria without a Secondary Market. The Quantity Surveyor, Vol. 38, No.1, January-March, pp. 22-37.

[9] Ogedengbe, P.S., Adesopo, A.A (2003). Problem of Financing Real Estate Development In Nigeria, Journal of Humanity and Ecology, Vol. 14, No. 6, pp. 425-431.

[10] Pencom, (2007). Annual Report. Retrieved from www.pencom.gov.ng on 26 February, 2011.

[11] Pencom, (2008).Annual Report. Retrieved from www.pencom.gov.ng on 26 February, 2011. 
[12] Pencom, (2010). Annual Report. Retrieved from www.pencom.gov.ng on 26 February, 2011.

[13] Pension Reform Act (2004). National Pension Commission, Retrieved from www.pencom.gov.ngon26 February, 2011.

[14] Gunu, U \& Tsado, E (2012) Contributory Pension System as a Tool for Economic Growth in Nigeria, International Journal of Business and Behavioral Sciences, 2(8).

[15] Odia, J.O and Okoye, A. E. (2012) Pensions Reform In Nigeria: A Comparison Between The Old And New Scheme. Afro Asian Journal of Social Sciences, 3(3.1).

[16] Renaud, B.M (2004). Mortgage Finance in Emerging Market: Constraints on feasible development paths, paper presented at USC FBE/LUSK Real Estate Seminar.

[17] Sogunle, D (2011). Pension Funds and Investment in Bonds paper presented At The Bond Training Workshop for Accountants and Insurance Companies Organized By NAICOM and SEC Lagos, 27 Sep 2011.

[18] World Bank, (2009). World Bank development Indicators 2009. Washington D.C.

[19] Sule, K.O., Umogbai, M. E. \& Emerole, G.A. (2011). "The Impact of Asset Size Profitability on Funded Status of Employee Benefits by Quoted Firms in Nigeria". Information, Management and Business Review. Vol. 2, No. 33, Pp. 125-132.

[20] Enhancing Financial Innovation and Access (EFInA), Access to Financial Services in Nigeria 2008 National Survey.

[21] Gardner, D. (2007). Access to Housing Finance in Africa: Exploring the issues. Finmark trust, Zambia.

[22] Timothy O. Nubi (2000), Housing Finance In Nigeria Need For Re-Engineering, Ideal Habitat Cooperative Initiative.

[23] Brueggerman, W.B. and Fisher, J. D.(1997). Real Estate Finance and Investments Irwin McGraw-Hill Boston.

[24] Isaac, D. (1998). Property Investment, England Macmilian.

[25] London, S. (1996). Lure of Property Magnet, Financial Times, 23 September p. 19 in Isaac D Property Investment.

[26] Nubi, T.O and Adewunmi, Y.A. (2011). Issues Influencing Access of Pension Funds as A Housing Finance Instrument in Nigeria, Journal of contemporary issues in Real Estate. Estate Management Department University of Lagos Akoka, Lagos. 1(1)

[27] Udoetuk, N.V (2008). The Role of Pension Funds in Real Estate investment in Nigeria, Journal of Building, 1(1).

[28] Ojo, A.O. (2009). The Role Of Secondary Mortgage Ficility in expanding the availability of funds for mortgage finance in Nigeria. Unpublished M.Sc thesis submitted to the department of Real Estate and Construction Management, Royal Institute of Technology (KTH), Sweden.

[29] Yinka, K. (2011). "Intervention Funding". A must for Affordable Housing in Nigeria Finance. Internet Publication. Retrieved March 62013. 
[30] Uloma Charity Oguzor, International Letters of Social and Humanistic Sciences 4 (2014) 97-104.

[31] Pawa Tersoo, International Letters of Social and Humanistic Sciences 3 (2014) 26-36.

[32] Sele Sylvester Ebisin, International Letters of Social and Humanistic Sciences 2 (2014) $1-9$. 